\title{
BMJ Open Chemokine co-receptor usage in HIV-1-infected treatment-naïve voluntary counselling and testing clients in Southern Taiwan
}

\author{
Hung-Chin Tsai, ${ }^{1,2}$ Pei-Yun Chou, ${ }^{1,2}$ Shue-Ren Wann, ${ }^{1,2}$ Susan Shin-Jung Lee, ${ }^{1,2}$ \\ Yao-Shen Chen ${ }^{1,2}$
}

To cite: Tsai H-C, Chou P-Y, Wann S-R, et al. Chemokine co-receptor usage in HIV-1-infected treatmentnaïve voluntary counselling and testing clients in Southern Taiwan. BMJ Open 2015;5:e007334. doi:10.1136/bmjopen-2014007334

- Prepublication history for this paper is available online. To view these files please visit the journal online (http://dx.doi.org/10.1136/ bmjopen-2014-007334).

Received 4 December 2014 Revised 27 March 2015 Accepted 9 April 2015

CrossMark

\begin{abstract}
${ }^{1}$ Section of Infectious Diseases, Department of Medicine, Kaohsiung Veterans General Hospital, Kaohsiung, Taiwan ROC ${ }^{2}$ National Yang-Ming University, Taipei, Taiwan ROC
\end{abstract}

Correspondence to Dr Hung-Chin Tsai; hctsai1011@yahoo.com.tw and Dr Yao-Shen Chen; yschen@vghks.gov.tw

\section{ABSTRACT \\ Objective: The goal of this present study was to determine the proportion of CCR5-tropic and CXCR4-tropic viruses and impact of tropism test on clinical presentation, CD4 cell counts, viral load and genotypic drug resistance from drug-naïve, voluntary counselling and testing (VCT) clients in southern Taiwan.}

Design: This was a cross-sectional study. Plasma samples were collected from HIV-1-infected patients from January 2013 to December 2013; subjects were recruited from free VCT centres in southern Taiwan.

Setting: Taiwan.

Participants: Plasma samples from 108 HIV-1infected, treatment-naïve, VCT clients were analysed. HIV-1 strains were sequenced, genotype resistance was determined by a commercial kit (Viro-seq) and co-receptor tropism (CRT) was predicted by an internet tool geno2pheno [coreceptor], with a $10 \%$ falsepositive rate as the cut-off. Differences in progression markers, patient characteristics, VCT questionnaires and HIV subtype distribution were evaluated statistically.

Results: All the 108 VCT clients were male with $90 \%$ between the ages of 20 and 40 years. Eighty-eight per cent of the patients were men who have sex with men (MSM). The median (IQR) CD4 cell count was 342 cells/ $\mu \mathrm{L}(221-454)$ and the viral load was 4.6 log (4.0-5.0). HIV-transmitted drug resistance was found in $9.3 \%(10 / 108)$ of the patients. CRT predictions indicated that $74 \%$ of the patients had only R5-tropic strains. CRT was not associated with CD4 cell counts, patient characteristics, VCT questionnaire and transmitted drug resistance. There was a significant difference with regard to viral load at the time of presentation, showing that patients with R5 more often had a higher viral load as compared with those with $X 4 / D M$ strains $(4.6 \pm 0.6 \log$ vs $4.33 \pm 0.7 \mathrm{log}$, $\mathrm{p}=0.036$ ).

Conclusions: We found that $74 \%$ of the VCT clients were infected with R5-tropic virus strains. HIVtransmitted drug resistance was not associated with CRT predictions. Higher viral load at presentation was predictive of R5 co-receptor usage.

\section{Strengths and limitations of the study}

- This study uses a genotypic prediction system which may result in a misclassification of the $\mathrm{R} 5$ virus as $\mathrm{X} 4$. The geno2pheno design is to predict unknown variants or variants with a poor sequence rather $\mathrm{X} 4$ instead of R5 and thus may result in an overcalling of $X 4$.

- Different co-receptor tropism prediction methods might yield different results.

- Rescreening by Enhanced Sensitivity Trofile assay (ESTA) and population-based sequencing predicted similar virological response in the MERIT trial.

- Study population consisted of young, mostly men who have sex with men, patients with HIV subtype $B$ infection, and the results might not be generalisable to other subtypes and populations.

\section{INTRODUCTION}

HIV entry into host cells requires coordinated interactions of the envelope glycoprotein gp120 with the CD4 receptor and with one of the chemokine receptors, CCR5 or CXCR4. ${ }^{1-6}$ Pure CCR5-tropic and pure CXCR4-tropic virus can use only the CCR5 and CXCR4 co-receptors to enter target cells, while dual-tropic virus can use both co-receptors. ${ }^{1-6}$ The study of HIV-1 co-receptor usage has clinical significance due to its strong correlation with the rate of disease progression in HIV-1-infected individuals. ${ }^{7-9}$ Determining HIV-1 co-receptor usage is also important since the CCR5 co-receptor has become the target of a new class of anti-HIV-1 drugs that specifically inhibit the entry of CCR5tropic HIV-1 strains into the target cells. Maraviroc was the first approved CCR5 antagonist and was used in clinical practice starting in 2007. Assessment of HIV-1 co-receptor usage is mandatory for the clinical use of this drug. ${ }^{10-14}$ 
Currently, the most widely used co-receptor tropism tests are the recombinant phenotypic Trofile assay (Monogram Biosciences) and its newer version, the Enhanced Sensitivity Trofile assay (ESTA).${ }^{15}{ }^{16}$ Despite their widespread use, there are some practical limitations to these assays, including a long turnaround time, restricted geographic access and the large sample volume they require. Genotypic tropism testing is an alternative method that is possible because the sequence of the third variable (V3) loop of gp120 is the principal determinant of tropism, allowing tropism inference using bioinformatic algorithms, such as PSSMx4/R5 and geno2pheno ${ }_{\text {[coreceptor] }}(\mathrm{g} 2 \mathrm{p}) .{ }^{17-21}$ The use of maraviroc is recommended for the treatment of antiretroviral-resistant patients failing prior regimens and also antiretroviral-naïve patients. ${ }^{12} \mathrm{~A}$ previous study in Mainland China showed that patients with HIV subtype B strains were more sensitive to maraviroc compared to patients with HIV subtype CRF07_BC. ${ }^{22}$ Therefore, it is necessary to understand the HIV subtype distribution and tropism diversity in our community before using this drug.

In Taiwan, the impact of HIV epidemiological data, transmitted drug resistance, risk factor for HIV acquisition and co-receptor usage in HIV-infected treatment naïve individuals, are unknown. Our objectives were to establish the prevalence of co-receptor use among the voluntary counselling and testing (VCT) clients with HIV infection, and to establish the clinical and viral characteristics, and transmitted drug resistance associated with and predictive of the presence of CCR-5 using the virus.

\section{MATERIAL AND METHODS \\ Ethical statements}

This study was approved by the institutional review board of the Kaohsiung Veterans General Hospital, Taiwan. The study complied with all ethical considerations involving human subjects. All information was obtained following standard clinical guidelines and all study participants understood the study procedure and provided signed informed consent.

\section{Study population}

Plasma samples collected from a consecutive group of individuals recruited from our free VCT centres at the Kaohsiung Veterans General Hospital from January 2013 to December 2013 ( $\mathrm{n}=108$ ) were analysed in this study. In Taiwan, 17 years ago, facilities offering VCT at no cost at the point of delivery were established and sponsored continuously by Taiwan Center for Diseases Control (CDC) as a key strategy to promote the early diagnosis and prevention of HIV, and others sexually transmitted diseases (STDs), and to stimulate referral to treatment. Taiwanese citizens can be tested for HIV infection for free, keeping anonymity, with easy access and in the context of a welcoming environment. For the study, the VCT procedure included a $30 \mathrm{~min}$ session of integrated pretesting and post-testing counselling; the clients then provided 5-10 $\mathrm{mL}$ of blood specimens for serological testing for HIV infection and syphilis. The VCT questionnaires recorded information including sociodemographics (age, sex, sexual orientation, occupation and education levels), sexual activity (numbers and timing of last anal/ oral/vaginal intercourse partners, history of STD), history of substance abuse, participants' attitudes towards the fear of acquiring or transmitting HIV/AIDS, frequency of condom use and reasons for access to VCT services.

Once the clients had received their reactive HIV ELISA or positive rapid test results, they were referred for clinical evaluation, western blot examination and treatment. HIV is a reportable disease in Taiwan and the government has been providing highly active antiretroviral therapy free of charge since its introduction in April 1997. The following laboratory exams were performed when the clients returned to the clinics, including the CD4 cell counts (FACS Flow, Becton Dickinson and Company, Franklin Lakes, New Jersey, USA), plasma viral load (Cobas Amplicor HIV-1 monitor test, V.1.5. Roche Diagnostics Corporation, Indianapolis, Indiana, USA), serological markers for syphilis, hepatitis A, B and C, Cryptococcus, toxoplasmosis, cytomegalovirus and amoebiasis, as well as cortisol level and liver, renal and thyroid function. The diagnosis of primary HIV-1 infection was based on any of the following: (1) patients who had recent high-risk behaviour, relatively high viral loads and normal CD4 counts, and compatible retroviral symptoms 3 months before serological positivity; (2) a positive enzyme immunoassay test for HIV-1 with indeterminate western blot results and one positive results for reverse transcriptase-PCR; or (3) negative serological tests 6 months prior to symptoms compatible with primary HIV-1 infection, with positive HIV ELISA and western blot results. ${ }^{23}$

\section{Genotypic drug resistance testing}

Resistance testing was performed on plasma samples using the ViroSeq HIV-1 Genotyping System version V.2.0, according to the manufacturer's instructions (Celera, Alameda, California, USA). Antiretroviral resistance mutations were interpreted with the HIVdb programme of the Stanford University HIV Drug Resistance Database. The patients classified as low-level resistance, intermediate resistance and high-level resistance were defined as having drug resistance.

\section{Genotypic tropism testing}

Viral RNA extraction, cDNA synthesis and nested PCR

RNA was extracted from $500 \mu \mathrm{L}$ of blood plasma by QIAamp Viral RNA Mini kit (Qiagen, Hilden, Germany). The plasma underwent one hour centrifugation at $28000 \times g$ at $4^{\circ} \mathrm{C}$ to concentrate the virus prior to extraction. The extracted viral RNA was eluted into a $60 \mu \mathrm{L}$ aliquot and stored at $-20^{\circ} \mathrm{C}$ or reverse transcriptase-PCR was initiated immediately after extracting. RNA was reverse transcribed with primer V3F1 (5'-GAGCCAATTCCCATACATTATTGT-3') and V3R1 (5'-GCCCATAGTGCTTCGTGCTGCTCCCAAGAACG-3') . 
The RT-PCR reaction mixture contained $7 \mu \mathrm{L}$ of RNA extract, $\times 2$ Reaction Mix (a buffer containing $0.4 \mathrm{mM}$ of each dNTP, $2.4 \mathrm{nM} \mathrm{MgSO}_{4}$ ), $5 \mathrm{mM}$ magnesium sulfate, $1 \mu \mathrm{L}$ SuperScript III One-Step RT-PCR System with Platinum Taq DNA Polymerase (Invitrogen) and $0.2 \mu \mathrm{M}$ primer V3F1 and V3R1. The amplification profile for cDNA synthesis and first PCR was: $30 \mathrm{~min}$ at $60^{\circ} \mathrm{C}$ (cDNA synthesis), $2 \mathrm{~min}$ at $94^{\circ} \mathrm{C}, 40$ cycles of (30 s at $94^{\circ} \mathrm{C}, 30 \mathrm{~s}$ at $55^{\circ} \mathrm{C}$ and $4 \mathrm{~min}$ at $68^{\circ} \mathrm{C}$ ) and $7 \mathrm{~min}$ at $68^{\circ} \mathrm{C}$. Then, the cDNA was amplified by a nested PCR protocol using primer V3F2 (5'-TGTGCCCCAGCTGG TTTTGCGAT-3') and V3R2 in (5'-TATAATTCACTTCTC CAATTGTCC-3'). The cycling profile was $2 \mathrm{~min}$ at $95^{\circ} \mathrm{C}$, 35 cycles of $\left(30 \mathrm{~s}\right.$ at $95^{\circ} \mathrm{C}, 30 \mathrm{~s}$ at $55^{\circ} \mathrm{C}$ and $3 \mathrm{~min}$ at $72^{\circ} \mathrm{C}$ ) and $7 \mathrm{~min}$ at $72^{\circ} \mathrm{C}$. After amplification, the product $(5 \mu \mathrm{L})$ was detected by ethidium bromide staining on $1.5 \%$ agarose gels and the remaining volume $(45 \mu \mathrm{L})$ was used for sequencing. ${ }^{13}$

\section{Sequencing and prediction of CRT}

The PCR product $(45 \mathrm{~mL})$ was purified using a QIAquick PCR Purification Kit (Qiagen, Heiden, Germany). The purified DNA was sequenced using a BigDye Terminator V.3.1 Cycle Sequencing Kit (ABI, USA), the mixture contained $3 \mu \mathrm{L}$ of purified template, $2 \mu \mathrm{L}$ of $3.1 \mathrm{big}$ dye and $4 \mu \mathrm{L}$ of the respective primer SQV3F (5'-AATGTCAGYACAGTACAATGTACAC-3') and SQV3R (5'-GAAAAATTCCCTTCCACAATTAAA-3'). The cycle sequencing profile was $2 \mathrm{~min}$ of $96^{\circ} \mathrm{C}, 25$ cycles of $\left(96^{\circ} \mathrm{C}\right.$ for $10 \mathrm{~s}, 50^{\circ} \mathrm{C}$ for $5 \mathrm{~s}$ and $60^{\circ} \mathrm{C}$ for $\left.4 \mathrm{~min}\right)$ followed by incubation at $4^{\circ} \mathrm{C}$. The sequencing fragments were purified using $75 \%$ 2-propanol.

Sequencing was performed on an ABI Prism 3130 Genetic Analyser. Using ReCall, a base calling software, automatic base for single primer coverage was performed and a 'Fasta' file was loaded. The CRT of all samples was predicted by using the geno2pheno ${ }_{\text {[coreceptor] }}$ service at the following web site URL:http://coreceptor.bioinf. mpi-inf.mpg.de/index.php.

All of the samples were run in triplicate and the sequence prediction results above a false-positive rate of $10 \%$ were considered as CCR5 tropic. Those at or below a false-positive rate of $10 \%$ were considered CXCR4 or D/M tropic.

\section{Statistics}

Mann-Whitney $\mathrm{U}$ test were used to compare the median values of continuous variables between the two groups (R5 and X4), respectively, and Fisher's exact test was used to compare categorical variables between the two groups as appropriate. Logistic regression analysis was used to determine the factors associated with R5-tropic genotype. Variables with a $\mathrm{p}$ value of $<0.2$ from univariate analysis were included in the logistic regression model. The OR and its 95\% CI were estimated. A twosided $\mathrm{p}$ value $<0.05$ was considered to be statistically significant. Statistical calculations were performed using SPSS program V.12.0 (SPSS Inc, Chicago, Illinois, USA).

\section{RESULTS}

From January 2013 to December 2013, a total of 4000 clients anonymously received VCT at our site with 120 clients $(3 \%)$ being diagnosed as having HIV-1 infection. Among them, 108 patients returned for outpatient visits

Table 1 Demographic data and HIV drug resistance among 108 HIV-1-infected treatment naïve VCT clients

\section{Parameters}

Patient numbers (\%)

Sex

Male

Age

20-29

$108(100 \%)$

30-39

$54(50 \%)$

$40-49$

$44(40.7 \%)$

$>50$

$8(7.4 \%)$

$2(1.9 \%)$

Risk factor

Heterosexual $13(12 \%)$

MSM

$95(88 \%)$

V3 co-receptor

CXCR4

CCR5

$28(25.9 \%)$

$80(74.1 \%)$

HIV subtype $(n=102)$

B

$101(99 \%)$

C

$1(1 \%)$

Hepatitis A antibody $(n=97)$

Positive

$9(9.3 \%)$

HBs Ag $(n=107)$

Positive

Antihepatitis B surface antibody ( $n=99)$

Positive

Antihepatitis B core antibody ( $n=99)$

Positive

Hepatitis $C$ antibody $(n=106)$

Positive

$14(13.1 \%)$

$54(54.5 \%)$

$39(39.4 \%)$

GOT (range 0-35 U/L)

Median (IQR)

GPT (range 0-40 U/L)

Median (IQR)

Cortisol $(\mu \mathrm{g} / \mathrm{dL}$ ) (normal range 3.1-22.4 $\mu \mathrm{g} / \mathrm{dL}$ )

Median (IQR)

$5(4.7 \%)$

$22(19-27)$

25 (16-35)

FreeT4 (ng/dL) (nor

$13.3(9.8-15.7)$

Median (IQR)

Syphilis serology

Positive

IHA-Amoebiasis $\geq 32(n=100)$

Positive

CMV-lgG $(n=66)$

Positive

Toxoplasma-lgG $(n=99)$

Positive

HIV viral load (log) (IU/mL)

Median (IQR)

CD4 count (cells $/ \mu \mathrm{L})$

Median (IQR)

HIV drug-resistance associated mutation

Resistance

$1.23(1.08-1.31)$

$48(44.4 \%)$

$8(8.0 \%)$

$64(97.0 \%)$

$4(4.5 \%)$

$4.6(4.0-5.0)$

CMV, cytomegalovirus; GOT, glutamic oxaloacetic transaminase; GPT, glutamic pyruvic transaminase; HBs Ag, hepatitis B surface antigen; IHA, indirect haemagglutination; MSM, men who have sex with men. 
and none had had a history of exposure to antiretroviral drugs before. Primary HIV infection was identified in 21 patients. The median time (IQR) from VCT to first evaluation for $\mathrm{CD} 4$, viral load, CRT and resistance testing was 13 (8-21.7) days.

All 108 patients were male with $90 \%$ between the ages of 20-39 years. Eighty-eight per cent of the clients were men who had sex with men (MSM). Six per cent of the patients had self-reported having a history of STD. Sixteen per cent of the patients had ever used illicit drugs. Twenty-eight per cent of the patients had more than six sexual partners and most had experienced anal $(84 \%)$ or oral sex $(91 \%)$. More than $65 \%$ of the patients had unprotected sexual intercourse 3 months before presentation, and $55 \%$ of the clients never or seldom used a condom. The seroprevalence rate for hepatitis A, $\mathrm{B}$ and $\mathrm{C}$ were $9.3 \%, 13 \%$ and $4.7 \%$, respectively. The prevalence rate for syphilis, amoebiasis (defined as indirect haemagglutination $\geq 1: 32$ ) and Toxoplasma gondii were $44.4 \%, 8 \%$ and $4.5 \%$, respectively. One patient with CXCR4 virus had a higher $(26 \mu \mathrm{g} / \mathrm{dL})$ serum cortisol level (normal range 3.1-22.4 $\mu \mathrm{g} / \mathrm{dL}$ ) and two patients with CCR-5 tropic virus had lower serum cortisol levels $(0.8 \mu \mathrm{g} / \mathrm{dL}$ and $1 \mu \mathrm{g} / \mathrm{dL}$, respectively; table 1$)$. The medium CD4 cell counts (IQR) were 342 (221-454) cells $/ \mu \mathrm{L}$, viral load (IQR) $4.6 \log (4.0-5.0)$. All of the 107 patients were HIV subtype B, only one patient had subtype C. This patient was a sailor and he got HIV infection in India. Nine per cent $(10 / 108)$ of the clients harboured transmitted drug resistance to antiretroviral drugs (table 1). One patient had a M184V mutation and all of the 10 subjects were resistant to non-nucleoside reverse-transcriptase inhibitors (NNRTI). No subject was resistant to protease inhibitors. The most common drug resistance associated mutations were V179D $(n=4)$, K013N (n=2), G190A $(n=1)$, M230L $(n=1)$, Y188C $(n=1)$ and V179E $(\mathrm{n}=1)$. CRT predictions indicated that $74 \%$ $(80 / 108)$ of the patients had only R5-tropic strains. There was no difference in the frequency of $\mathrm{X} 4$ viruses

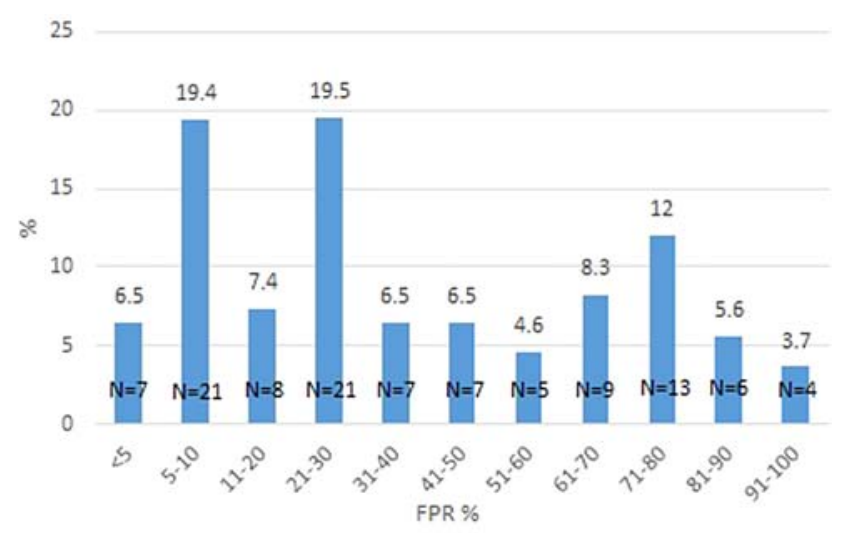

Figure 1 The distributions of false-positive rate (FPR) \% for CRT among 108 patients are shown in figure 3. A total of $74 \%$ of the patients had only R5-tropic strains (FPR 10\%). in single analysis or triplicate testing. The distribution of FPR (\%) among the 108 patients is shown in figure 1. There was no association between $\mathrm{CD} 4$ cell counts, risk factor for HIV acquisition by VCT questionnaires, HIV subtype, opportunistic infection markers and transmitted drugs resistance with presence of R5-tropic virus. The factor associated with presence of R5-tropic virus in single variance analysis was plasma viral load $(4.6 \pm 0.6$ vs $4.33 \pm 0.7$ ), $\mathrm{p}=0.036,95 \%$ CI 1.05 to 4.33 (tables $2-4$ and figures 2 and 3). After we excluded 21 patients with primary HIV infection who were thought to have a higher viral load, the statistics were still found to be significant $(\mathrm{p}=0.037)$. Age, anti-HCV antibody positive and plasma viral load that had a $\mathrm{p}$ value of $<0.2$ were put

Table 2 The sociodemographic and sexual history in VCT questionnaires among 108 attendees in southern Taiwan

\begin{tabular}{|c|c|}
\hline Parameters & Patient numbers (\%) \\
\hline \multicolumn{2}{|l|}{ Marital status $(n=105)$} \\
\hline Unmarried & $102(97.1)$ \\
\hline \multicolumn{2}{|l|}{ Educational level $(n=104)$} \\
\hline Senior high school or below & $23(22.1)$ \\
\hline College level or higher & 81 (77.9) \\
\hline \multicolumn{2}{|l|}{ Occupation $(n=105)$} \\
\hline Full-time job & $62(59)$ \\
\hline \multicolumn{2}{|c|}{ History of sexually transmitted diseases $(n=105)$} \\
\hline Yes & $6(5.7)$ \\
\hline \multicolumn{2}{|c|}{ History of using illicit drugs $(n=105)$} \\
\hline Yes & $17(16.2)$ \\
\hline \multicolumn{2}{|c|}{ Number of sexual partners more than $5(n=74)$} \\
\hline Yes & $21(28.4)$ \\
\hline \multicolumn{2}{|c|}{ Number of sexual partners more than $10(n=74)$} \\
\hline Yes & $6(8.1)$ \\
\hline \multicolumn{2}{|l|}{ History of anal intercourse $(n=79)$} \\
\hline Yes & $66(83.5)$ \\
\hline \multicolumn{2}{|l|}{ History of oral sex $(n=79)$} \\
\hline Yes & $72(91.1)$ \\
\hline \multicolumn{2}{|c|}{$\begin{array}{l}\text { History of unprotected sexual intercourse in past } 3 \text { months } \\
(n=66)\end{array}$} \\
\hline Yes & $43(65.2)$ \\
\hline \multicolumn{2}{|c|}{ Frequency of condom use $(n=101)$} \\
\hline Every time use or almost use & 45 (44.6) \\
\hline Occasional or never use & $56(55.4)$ \\
\hline \multicolumn{2}{|l|}{ History of HIV VCT before $(n=85)$} \\
\hline Yes & $40(47.1)$ \\
\hline \multicolumn{2}{|l|}{ Reasons for HIV VCT } \\
\hline \multicolumn{2}{|c|}{ Suspect HIV infection by attendee himself $(n=101)$} \\
\hline Yes & $73(72.3)$ \\
\hline \multirow{2}{*}{\multicolumn{2}{|c|}{$\begin{array}{l}\text { Suspect wife/husband or sexual partners infected with } \\
\text { HIV ( }=79)\end{array}$}} \\
\hline & \\
\hline Yes & $33(41.8)$ \\
\hline \multicolumn{2}{|c|}{$\begin{array}{l}\text { Wife/husband or sexual partners were infected with HIV } \\
(n=79)\end{array}$} \\
\hline Yes & $7(8.9)$ \\
\hline \multicolumn{2}{|c|}{$\begin{array}{l}\text { Recent history of prostituting, one-night stand or joining } \\
\text { sexual home party }(n=93)\end{array}$} \\
\hline Yes & $65(69.9)$ \\
\hline
\end{tabular}


Table 3 Correlation of clinical manifestations, laboratory data and chemokines co-receptor tropism usage among 108 VCT attendees in southern Taiwan

\begin{tabular}{|c|c|c|c|c|c|}
\hline & CXCR4 & CCR5 & p Value & OR & $95 \% \mathrm{Cl}$ \\
\hline Total, n (\%) & $28(26)$ & $80(74)$ & NA & & \\
\hline Age (median; IQR) & $31.5(27.2-34.7)$ & $28.5(25-28.5)$ & 0.15 & 0.97 & 0.92 to 1.03 \\
\hline \multicolumn{6}{|l|}{ Risk factor $\mathrm{n}(\%)$} \\
\hline Heterosexual & $3(10.7)$ & $10(12.5)$ & 1.0 & 1.19 & 0.30 to 4.68 \\
\hline MSM & $25(89.3)$ & $70(87.5)$ & & & \\
\hline Viral load (log) (median; IQR) & $4.2(3.8-4.8)$ & $4.7(4.1-5.0)$ & 0.036 & 2.14 & 1.05 to 4.33 \\
\hline WCC (median; IQR) & $5810(4462-6692)$ & $5430(4615-6922)$ & 0.88 & 1.0 & 1.0 to 1.0 \\
\hline CD4 (median; IQR) & $316(210-459)$ & $348(207-454)$ & 0.61 & 0.99 & 0.99 to 1.0 \\
\hline \multicolumn{6}{|l|}{ HIV subtype $n(\%)$} \\
\hline Non-B & 0 & $1(1.4)$ & 1.0 & - & - \\
\hline B & $28(100)$ & $73(98.6)$ & & & \\
\hline HIV drug-resistance associated mutation & $4 / 28(14.3)$ & $6 / 80(7.5)$ & 0.28 & 2.05 & 0.53 to 7.90 \\
\hline Hepatitis A antibody & $4 / 25(16.0)$ & $5 / 72(6.9)$ & 0.23 & 2.55 & 0.62 to 10.38 \\
\hline $\mathrm{HBs} \mathrm{Ag}$ & $5 / 28(17.9)$ & $9 / 79(11.4)$ & 0.51 & 1.69 & 0.51 to 5.56 \\
\hline Antihepatitis B surface antibody & $13 / 25(52.0)$ & $41 / 74(55.4)$ & 0.77 & 0.87 & 0.35 to 2.16 \\
\hline Antihepatitis B core antibody & $11 / 25(44)$ & $28 / 74(37.8)$ & 0.58 & 1.29 & 0.51 to 3.23 \\
\hline Hepatitis C antibody & $3 / 28(10.7)$ & 2/78 (2.6) & 0.11 & 4.56 & 0.72 to 28.86 \\
\hline GOT (U/L) (median; IQR) (range 0-35 U/L) & $21(18.5-24)$ & $22(19-28.7)$ & 0.17 & 1.05 & 0.99 to 1.13 \\
\hline GPT (U/L) (median; IQR) (range 0-40 U/L) & $20(15.5-29)$ & $25(17.2-37)$ & 0.10 & 1.02 & 0.98 to 1.05 \\
\hline $\begin{array}{l}\text { Cortisol }(\mu \mathrm{g} / \mathrm{dL} \text { ) (median; IQR) (normal } \\
\text { range } 3.1-22.4 \mu \mathrm{g} / \mathrm{dL} \text { ) }\end{array}$ & $11.2(8.9-14.3)$ & $14(10-16.1)$ & 0.11 & 1.06 & 0.95 to 1.18 \\
\hline $\begin{array}{l}\text { FreeT4 }(\mathrm{ng} / \mathrm{dL})(\text { median; IQR) (normal } \\
\text { range } 0.8-1.9 \mu \mathrm{g} / \mathrm{dL} \text { ) }\end{array}$ & $1.19(1.13-1.3)$ & $1.23(1.07-1.32)$ & 0.90 & 1.06 & 0.01 to 71.94 \\
\hline Syphilis & $12 / 28(42.9)$ & $36 / 80(45)$ & 0.51 & 0.91 & 0.38 to 2.18 \\
\hline IHA-Amoebiasis $\geq 32$ & 2/24 (8.3) & $6 / 76(7.9)$ & 1.0 & 1.06 & 0.20 to 5.63 \\
\hline CMV-lgG & $19 / 19(100)$ & $45 / 47(95.7)$ & 1.0 & - & - \\
\hline Toxoplasma-IgG & $0 / 24$ & $4 / 75(5.3)$ & 0.57 & - & - \\
\hline
\end{tabular}

CMV, cytomegalovirus; GOT, glutamic oxaloacetic transaminase; GPT, glutamic pyruvic transaminase; IHA, indirect haemagglutination;

MSM, men who have sex with men; VCT, voluntary counselling and testing; WCC, white cell count.

into a logistic regression model, and we found that those patients with a higher viral load were still at a statistically significantly higher risk of being infected with R5-tropic viruses, with an adjusted OR of 2.07 (95\% CI 1.024 to 4.193; $\mathrm{p}=0.043$ ).

\section{DISCUSSION}

We observed a significant association among HIV-1 RNA load and chemokine co-receptor use. Patients with R5-tropic virus had higher plasma viral load compared to patients harbouring X4/DM strains. Associations between HIV-1 RNA load and CD4 cell count, and co-receptor usage, have been reported elsewhere. ${ }^{7-9}$ Co-receptor use has been considered as a determinant of disease progression, and those individuals with virus using the CCR5 co-receptor generally have a slower rate of progression and lower viral load than those with virus using CXCR4. The treatment of HIV-infected individuals by using CCR5 antagonists represents a new therapeutic advance that may require a reliable determination of co-receptor use status. ${ }^{10-12}$

Previous studies in Western countries, where HIV-1 subtype B predominates, reported that $80-90 \%$ of untreated HIV-1-infected patients ${ }^{24}$ harboured R5 strains. In a study from Spain, the researchers showed that $13.4 \%$ of the 67 HIV-1 seroconverters harboured CXCR4 viruses. ${ }^{25}$ A French study also showed that $15.9 \%$ of 390 primary HIV subtype B infection contained X4 viruses. ${ }^{26}$ In a sexually infected HIV and treatment naive cohort from China, researchers found that the CRF01_AE subtype was predominant (46\%), especially in the MSM group. The study revealed that the proportion of $\mathrm{X} 4$ tropism was higher in the CRF01_AE subtype (45.5\%) than in others (C/CRF07_BC/CRF08_BC, 4.3\%; B, $6.1 \% ; \mathrm{p}<0.001)$. CRF01_AE subtype was associated with faster progression to AIDS. ${ }^{27}$ Another study from Hong Kong by To $e t a l,{ }^{28}$ showed that the prevalence of Dual/ Mixed-virus or X4-tropic virus in antiretroviral-naive subtype CRF01_AE was 24\% (21/87), which was significantly higher than subtype B $14 \%(15 / 104)$ if using geno2pheno $_{\text {[coreceptor] }}$ with a $10 \%$ false-positive rate as the cut-off.

Our study showed that only $74 \%$ of treatment naive patients had R5-tropic virus. The results in our study were similar to the study of Meini $e t a l,{ }^{29}$ which showed that $26.2 \%$ of HIV infected treatment-naive patients in Italy had non-CCR5-tropic viruses. This discrepancy in prevalence of co-receptor use in different studies might be due to the different patient populations, stage of HIV infection (primary vs chronic infection) and methodology of co-receptor use tropism. Studies, such as 
Table 4 Correlation of VCT questionnaires and chemokines co-receptor tropism usage among 108 VCT attendees in southern Taiwan

\begin{tabular}{lcccll}
\hline & CXCR4 & CCR5 & p Value & OR & 95\% CI \\
\hline Married & $2 / 28(7.1)$ & $1 / 77(1.3)$ & 0.17 & 5.84 & 0.51 to 67.17 \\
Educational level & $4 / 27(14.8)$ & $19 / 77(24.7)$ & 0.42 & 0.53 & 0.16 to 1.73 \\
Occupation & $13 / 28(46.4)$ & $30 / 77(39.0)$ & 0.50 & 1.35 & 0.56 to 3.25 \\
History of sexually transmitted diseases & $3 / 28(10.7)$ & $3 / 77(3.9)$ & 0.33 & 2.96 & 0.56 to 15.61 \\
History of using illicit drugs & $2 / 28(7.1)$ & $15 / 77(19.5)$ & 0.22 & 0.32 & 0.07 to 1.49 \\
History of anal intercourse & $15 / 19(78.9)$ & $51 / 60(85.0)$ & 0.50 & 0.66 & 0.18 to 2.45 \\
History of oral sex & $16 / 19(84.2)$ & $56 / 60(93.3)$ & 0.35 & 0.38 & 0.07 to 1.88 \\
History of unprotected sexual intercourse in past 3 months & $12 / 17(70.6)$ & $31 / 49(63.3)$ & 0.76 & 1.39 & 0.42 to 4.60 \\
Frequency of condom use & $14 / 26(53.8)$ & $31 / 75(41.3)$ & 0.36 & 1.65 & 0.67 to 4.06 \\
$\quad$ History of HIV VCT before & $11 / 23(47.8)$ & $29 / 62(46.8)$ & 1.00 & 1.04 & 0.40 to 2.71 \\
Reasons for HIV VCT & & & & & \\
$\quad$ Suspect HIV infection by attendee himself & $17 / 26(65.4)$ & $56 / 75(74.7)$ & 0.44 & 0.64 & 0.24 to 1.67 \\
$\quad$ Suspect wife/husband or sexual partners infected with HIV & $7 / 19(36.8)$ & $26 / 60(43.3)$ & 0.79 & 0.76 & 0.26 to 2.20 \\
$\quad$ Wife/husband or sexual partners were infected with HIV & $1 / 19(5.3)$ & $4 / 60(10)$ & 1.00 & 0.50 & 0.05 to 4.43 \\
$\quad$ Recent history of prostituting, one-night stand or joining & $16 / 25(64.0)$ & $49 / 68(72.1)$ & 0.45 & 0.69 & 0.26 to 1.82 \\
$\quad$ & & & & &
\end{tabular}

ours, based on genotypic methods, generally reported a higher CXCR4 prevalence.

We also did not find a strong association between a low $\mathrm{CD} 4$ count at baseline and the detection of $\mathrm{X} 4$ virus. Otherwise, the R5-tropic virus had a higher viral load as compared to the X4 strain. The statistics were still significant even though we excluded 21 patients with primary HIV infection who supposedly had an initially high baseline viral load. This discrepancy may be explained by the relatively small case numbers in our series, and different patient populations. Our patients were inducted from those VCT attendees with higher CD4 cell counts and were infected relatively recently. This could explain why they possessed relatively higher viral loads in contrast to other studies showing that patients harbouring the $\mathrm{X} 4$

CD4+ $\mathrm{T}$ cell count at time of diagnosis

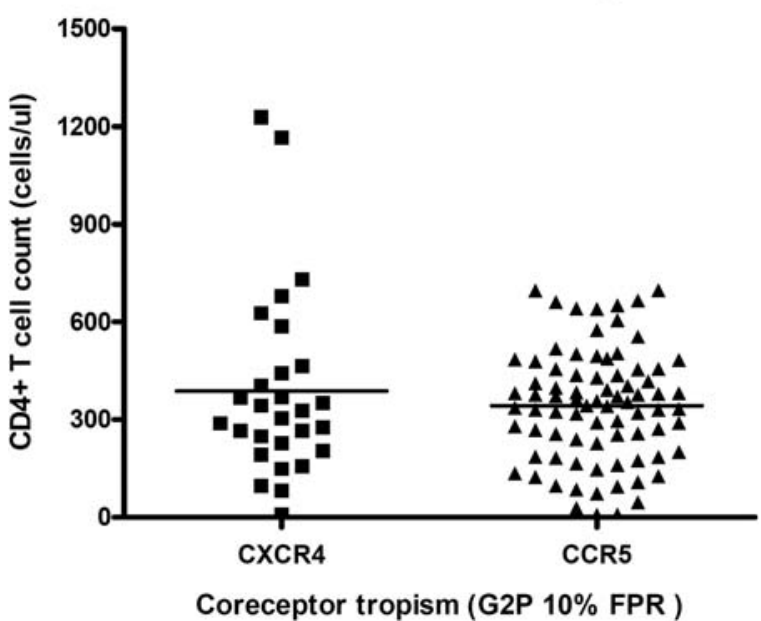

Figure 2 The CD4T cell counts were not statistically different among 108 patients with CCR-5 tropic and CXCR4 tropic virus. strain had a higher viral load. Further study is clearly needed to confirm this hypothesis.

HIV-transmitted drug resistance was $9.3 \%(10 / 108)$ in our VCT clients. In Southeast Asia, HIV-transmitted drug resistance rate was around $4-12 \%$, including $3.8 \%$ in China, ${ }^{30} 7.7 \%$ in Japan, ${ }^{31} 12 \%$ in South Korea, ${ }^{32} 4.9 \%$ in Thailand ${ }^{33}$ and $8 \%$ in northern Taiwan. ${ }^{34}$ Resistance rates varied according to the different populations enrolled. However, there are no data on the prevalence of HIV drug resistance in southern Taiwan, especially in those MSM receiving VCT. The samples from the 10 patients displayed NNRTI-related resistance mutations.

\section{HIV Viral load at time of diagnosis}

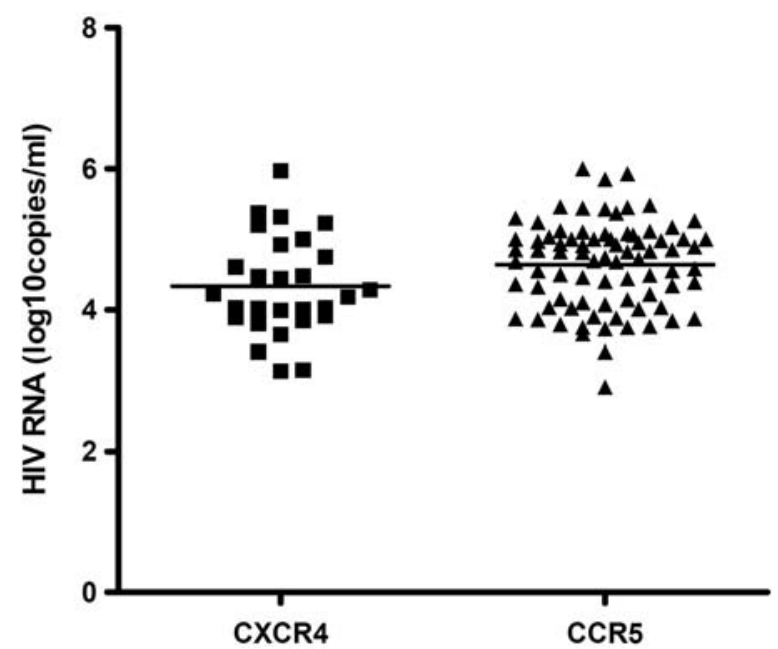

Coreceptor tropism (G2P 10 \% FPR)

Figure 3 The plasma viral load was higher in patients with CCR-5 tropic virus as compared to CXCR4 tropic virus (4.6 \pm 0.6 vs $4.33 \pm 0.7, p=0.036$ ). 
Since NNRTIs are the backbone of first-line antiretroviral therapy in Taiwan, further large-scale studies conducted on the transmission patterns or trends in drug resistance were would be welcome.

Our study had a number of limitations that should be highlighted. First, we used a population genotypic prediction system, which may result in a misclassification of the $\mathrm{R} 5$ virus as $\mathrm{X} 4$. More sensitive ultradeep pyrosequencing (UDS) can provide multiple orders of magnitude greater than conventional sequencing and can detect minority CXCR-4 using variants, but clinical superiority has not been validated so far. ${ }^{35}$ UDS and the phenotype were concordant for determining HIV-1 co-receptor usage during primary HIV infection. ${ }^{36}$ Second, different co-receptor tropism prediction methods (such as Web PSSM and Wet Cat) might yield different results. Furthermore, our study population consisted of young patients with MSM with HIV subtype B infection, and the results might not generalised to other subtypes and populations. Finally, the V3 loop was not the only determinant of tropism and, therefore, tropism predictions based on V3 loop sequences might not be accurate.

In summary, our study revealed a high $(9.3 \%)$ transmitted drug resistance rate among VCT clients. This finding reminds us of the urgent need for the improvement and implementation of a comprehensive public health strategy for HIV-1-transmitted drug resistance prevention. Chemokine co-receptor tropism of HIV is associated with HIV-1 RNA levels, and not associated with CD4 cell counts, viral subtype and clinical risk factors. The clinical impact of high viral load on patients' initiation of treatment with chemokine co-receptor antagonists remains to be determined.

Contributors THC, WSR and LSJ participated in the study design and preparation of the manuscript. THC, CPY and CYS participated in the laboratory experimental work and in interpretation of the data. All authors read and approved the final manuscript.

Funding This study was funded by Veterans General Hospitals and University System of Taiwan Joint Research Programme grant. VGHUST102-G3-1-1

Competing interests None declared.

Ethics approval This study was approved by the institutional review board of the Kaohsiung Veterans General Hospital, Taiwan.

Provenance and peer review Not commissioned; externally peer reviewed.

Data sharing statement The data cannot be shared without IRB approval. NO additional unpublished data can be shared.

Open Access This is an Open Access article distributed in accordance with the Creative Commons Attribution Non Commercial (CC BY-NC 4.0) license, which permits others to distribute, remix, adapt, build upon this work noncommercially, and license their derivative works on different terms, provided the original work is properly cited and the use is non-commercial. See: http:// creativecommons.org/licenses/by-nc/4.0/

\section{REFERENCES}

1. Berger EA, Murphy PM, Farber JM. Chemokine receptors as HIV-1 coreceptors: roles in viral entry, tropism, and disease. Annu Rev Immunol 1999;17:657-700.
2. Shioda T, Levy JA, Cheng-Mayer C. Macrophage T cell line-tropisms of HIV-1 are determined by specific regions of the envelope gp120 gene. Nature 1991;349:167-9.

3. De Jong JJ, De Ronde A, Keulen W, et al. Minimal requirements for the human immunodeficiency virus type $1 \mathrm{~V} 3$ domain to support the syncytium-inducing phenotype: analysis by single amino acid substitution. J Virol 1992;66:6777-80.

4. Chan S, Speck R, Power C, et al. V3 recombinants indicate a central role for CCR5 as coreceptor in tissue infection by HIV type 1. $J$ Virol 1999;73:2350-8.

5. Kwong PD, Wyatt R, Robinson J, et al. Structure of an HIV gp120 envelope glycoprotein in complex with the CD4 receptor a neutralizing human antibody. Nature 1998;393:648-59.

6. Hoffman NG, Seillier-Moiseiwitsch F, Ahn J, et al. Variability in the human immunodeficiency virus type $1 \mathrm{gp} 120$ Env protein linked to phenotype-associated changes in the V3 loop. $J$ Virol 2002;76:3852-64.

7. Koot M, van Leeuwen R, de Goede RE, et al. Conversion rate towards a syncytium-inducing (SI) phenotype during different stages of human immunodeficiency virus type 1 infection and prognostic value of SI phenotype for survival after AIDS diagnosis. $J$ Infect Dis 1999;179:254-8.

8. Furrer $\mathrm{H}$, Wendland $\mathrm{T}$, Minder $\mathrm{C}$, et al. Association of syncytium inducing phenotype of HIV-1 with CD4 cell count, viral load and sociodemographic characteristics. AIDS 1998;12:1341-6.

9. Bozzette SA, McCutchan JA, Spector SA, et al. A cross-sectiona comparison of persons with syncytium- and non-syn-cytium-inducing human immunodeficiency virus. J Infect Dis 1993;168:1374-9.

10. Soriano V, Geretti AM, Perno CF, et al. Optimal use of maraviroc in clinical practice. AIDS 2008;22:2231-40.

11. Dorr P, Westby M, Dobbs S, et al. Maraviroc (UK-427,857), a potent orally bioavailable, selective small-molecule inhibitor of chemokine receptor CCR5 with broad-spectrum anti-human immunodeficiency virus type 1 activity. Antimicrob Agents Chemother 2005;49: 4721-32.

12. Carter NJ, Keating GM. Maraviroc. Drugs 2007;67:2277-88.

13. McGovern RA, Harrigan PR, Swenson LC. Genotypic inference of HIV-1 tropism using population-based sequencing of V3. J Vis Exp 2010;(46):pii: 2531.

14. Swenson LC, Mo T, Dong WW, et al. Deep sequencing to infer HIV-1 co-receptor usage: application to three clinical trials of maraviroc in treatment-experienced patients. $J$ Infect Dis 2011;203:237-45

15. Whitcomb JM, Huang W, Fransen S, et al. Development characterization of a novel single-cycle recombinant-virus assay to determine human immunodeficiency virus type 1 coreceptor tropism. Antimicrob Agents Chemother 2007;51:566-75.

16. Reeves JD, Coakley E, Petropoulos CJ, et al. An enhancedsensitivity trofile assay. J Viral Entry 2009;3:94-102.

17. Rose JD, Rhea AM, Weber J, et al. Current tests to evaluate HIV-1 co-receptor tropism. Curr Opin HIV AIDS 2009;4:136-42.

18. Sierra S, Kaiser R, Thielen A, et al. Genotypic coreceptor analysis. Eur J Med Res 2007;12:453-62.

19. Fouchier RA, Brouwer M, Broersen SM, et al. Simple determination of human immunodeficiency virus type 1 syncytium inducing V3 genotype by PCR. J Clin Microbiol 1995;33:906-11.

20. Jensen MA, Li FS, van 't Wout AB, et al. Improved coreceptor usage prediction genotypic monitoring of R5-to- $\mathrm{X} 4$ transition by motif analysis of HIV-1 env V3 loop sequences. $J$ Virol 2003;77:13376-88.

21. Sing T, Low AJ, Beerenwinkel N, et al. Predicting HIV co-receptor usage based on genetic clinical covariates. Antivir Ther 2007;12:1097-106.

22. Yu X, Yuan L, Huang Y, et al. Susceptibility of HIV-1 subtypes B', CRF07_BC and CRF01_AE that are predominantly circulating in China to HIV-1 entry inhibitors. PLoS ONE 2011;6:e17605.

23. Schacker T, Collier AC, Hughes J, et al. Clinical and epidemiologic features of primary HIV infection. Ann Intern Med 1996;125:257-64.

24. Moyle GJ, Wildfire A, Mandalia S, et al. Epidemiology and predictive factors for chemokine receptor use in HIV-1 infection. J Infect Dis 2005;191:866-72.

25. de Mendoza C, Rodriguez C, García F, et al., Spanish HIV Seroconverter Study Group. Prevalence of X4 tropic viruses in patients recently infected with HIV-1 and lack of association with transmission of drug resistance. J Antimicrob Chemother 2007;59:698-704

26. Frange $\mathrm{P}$, Chaix ML, Raymond S, et al., French ANRS CO 06 PRIMO Cohort Study Group. Low frequency of CXCR4-using viruses in patients at the time of primary non-subtype-B HIV-1 infection. J Clin Microbiol 2010;48:3487-91. 
27. Li Y, Han Y, Xie J, et al. CRF01_AE subtype is associated with X4 tropism and fast HIV progression in Chinese patients infected through sexual transmission. AIDS 2014;28:521-30.

28. To SW, Chen JH, Wong $\mathrm{KH}$, et al. Determination of the high prevalence of Dual/Mixed- or X4-tropism among HIV type 1 CRF01_AE in Hong Kong by genotyping and phenotyping methods. AIDS Res Hum Retroviruses 2013;29:1123-8.

29. Meini G, Rossetti B, Bianco C, et al., on behalf of the ICONA Foundation Group. Longitudinal analysis of HIV-1 coreceptor tropism by single and triplicate HIV-1 RNA and DNA sequencing in patients undergoing successful first-line antiretroviral therapy. J Antimicrob Chemother 2014;69:735-41.

30. Liao $\mathrm{L}$, Xing $\mathrm{H}$, Shang $\mathrm{H}$, et al. The prevalence of transmitted antiretroviral drug resistance in treatment-naive HIV-infected individuals in China. J Acquir Immune Defic Syndr 2010:53:S10-14.

31. Hattori J, Shiino T, Gatanaga $\mathrm{H}$, et al. Trends in transmitted drug-resistant HIV-1 and demographic characteristics of newly diagnosed patients: nationwide surveillance from 2003 to 2008 in Japan. Antiviral Res 2010;88:72-9.
32. Kim MH, Song JE, Ahn JY, et al. HIV antiretroviral resistance mutations among antiretroviral treatment-naive and -experienced patients in South Korea. AIDS Res Hum Retroviruses 2013;29:1617-20.

33. Sungkanuparph S, Sukasem C, Kiertiburanakul S, et al. Emergence of HIV-1 drug resistance mutations among antiretroviral-naïve HIV-1-infected patients after rapid scaling up of antiretroviral therapy in Thailand. J Int AIDS Soc 2012;15:12.

34. Lai CC, Hung CC, Chen MY, et al. Trends of transmitted drug resistance of HIV-1 and its impact on treatment response to first-line antiretroviral therapy in Taiwan. $J$ Antimicrob Chemother 2012;67:1254-60

35. Bunnik EM, Swenson LC, Edo-Matas D, et al. Detection of inferred CCR5- and CXCR4-using HIV-1 variants and evolutionary intermediates using ultra-deep pyrosequencing. PLoS Pathog 2011; 7:e1002106.

36. Raymond S, Saliou A, Nicot F, et al. Characterization of CXCR4-using HIV-1 during primary infection by ultra-deep pyrosequencing. $J$ Antimicrob Chemother 2013;68:2875-8. 